\title{
Anaemia secondary to critical illness: an unexplained phenomenon
}

\author{
Ronan Astin $^{1 *}$ and Zudin Puthucheary ${ }^{1,2,3}$
}

\begin{abstract}
Almost all patients suffering critical illness become anaemic during their time in intensive care. The cause of this anaemia and its management has been a topic of debate in critical care medicine for the last two decades. Packed red cell transfusion has an associated cost and morbidity such that decreasing the number of units transfused would be of great benefit. Our understanding of the aetiology and importance of this anaemia is improving with recent and ongoing work to establish the cause, effect and best treatment options. This review aims to describe the current literature whilst suggesting that the nature of the anaemia should be considered with reference to the time point in critical illness. Finally, we suggest that using haemoglobin concentration as a measure of oxygen-carrying capacity has limitations and that ways of measuring haemoglobin mass should be explored.
\end{abstract}

Keywords: Neocytolysis, Total haemoglobin mass, Transfusion

\section{Review}

\section{Introduction}

Critically ill patients are regularly classified by physiological syndromes such as acute respiratory distress syndrome (ARDS), multi-organ dysfunction syndrome (MODS), systemic inflammatory response syndrome (SIRS), or clinical diagnoses such as severe sepsis, acute kidney injury or traumatic brain injury. These nomenclatures hide both the heterogeneity of the patients' presentation and the diverse diseases from which they may suffer pre-critical illness. Strikingly, despite this variation, it has been repeatedly shown that the vast majority of all patients requiring intensive care support display a falling haemoglobin concentration ([Hb]), with the majority becoming anaemic (as defined $[\mathrm{Hb}]<130 \mathrm{~g} / \mathrm{L}$ in males and $<120 \mathrm{~g} / \mathrm{L}$ in females) [1-4]. The cause of this falling [Hb] is not clear nor its impact on patient outcomes. This review considers the time frame of anaemia of critical illness and suggests that the aetiology is related to the illness phase. The likely causes of anaemia will be discussed, and the evidence for impact on patient outcome considered. Finally, the limitations of using $[\mathrm{Hb}]$ as an indicator of oxygen-carrying capacity will be

\footnotetext{
* Correspondence: ronan.astin@nhs.net

'Department of Medicine, UCL Institute for Human Health and Performance, University College London, 4th Floor, Rockefeller Building, 21 University Street, London WC1E 6DB, UK

Full list of author information is available at the end of the article
}

outlined, and the advantages of using total Hb-mass (tHb-mass) will be discussed.

\section{Time course of anaemia in critical illness}

Defining the temporal relationship between anaemia and critical illness is best done by dividing critical illness into three time periods:

- Pre-ICU admission

- The acute phase, covering approximately the first 7 days of ICU admission

- The chronic stage thereafter

Little is known regarding $[\mathrm{Hb}]$ in the lead up to ICU admission, but it is clear that on entering critical care, a large proportion of patients already have a low $[\mathrm{Hb}]$. Two large studies demonstrated this; in 3,534 general admissions to ICUs in Western Europe enrolled in the $\mathrm{ABC}$ trial, the mean admission $[\mathrm{Hb}]$ was $113 \pm 23 \mathrm{~g} / \mathrm{L}$ and $29 \%$ had $[\mathrm{Hb}]<100 \mathrm{~g} / \mathrm{L}$ [5], whilst in the 4,892 subjects enrolled to the CRIT study in general ICUs in North America, the mean baseline [Hb] was $110 \pm 24 \mathrm{~g} / \mathrm{L}$ [3]. A more recent study has put the proportion of patients admitted to ICU with $[\mathrm{Hb}]$ in the anaemic range even higher at $86 \%$ [6]. In a study of 1,023 patients admitted to 10 general ICUs in Scotland (ATICS study) each with a medical, surgical and trauma case-mix, the mean admission $[\mathrm{Hb}]$ 
was $105 \mathrm{~g} / \mathrm{L}$ and $25 \%$ had [Hb] $<90 \mathrm{~g} / \mathrm{L}$ [7]. By combining data from multiple large studies, Walsh and Saleh have estimated that $60 \%$ to $70 \%$ of patients are anaemic on entering ICU with $20 \%$ to $30 \%$ displaying $[\mathrm{Hb}]<90 \mathrm{~g} / \mathrm{L}$ [8]. However, the chronic (or non-chronic) nature of pre-ICU anaemia has not been widely studied. For the majority, though it seems unlikely to be longstanding; in both the $\mathrm{ABC}$ and CRIT studies, the proportion of patients entering ICU with a medical history of anaemia was only $13 \%$.

\section{The acute anaemia of critical illness}

Over the first few days of admission to critical care, $[\mathrm{Hb}]$ continues to fall. In a study of 155 ICU patients in a general ICU, the mean admission [Hb] was $111 \pm 25 \mathrm{~g} / \mathrm{L}$ but by the second time point on day 7 , this had fallen to $94 \pm 14 \mathrm{~g} / \mathrm{L}$ [2]. This is a pattern repeatedly demonstrated $[6,9,10]$. In the CRIT study, $44 \%$ of subjects required one or more units of packed red cells (PRC) transfused during their stay in ICU and the majority of these transfusions occurred early in their admission with a mean time to first transfusion of $2.3 \pm 3.7$ days (mean pre-transfusion $[\mathrm{Hb}] 86 \pm 17 \mathrm{~g} / \mathrm{L}$ from an admission level of $111 \mathrm{~g} / \mathrm{L}$ ) [3]. Chohan et al. showed that in a cohort of 176 patients admitted to a general ICU, $52 \%$ had $[\mathrm{Hb}]<90 \mathrm{~g} / \mathrm{L}$ on day one increasing to $77 \%$ by day two [11]. Nguyen et al. further defined the time course of this drop by demonstrating that over the course of an ICU stay, [Hb] fell on average $5.2 \pm 6.9 \mathrm{~g} / \mathrm{L}$ per day, but the decline was greatest over the first 3 days when $[\mathrm{Hb}]$ declined by $6.6 \mathrm{~g} / \mathrm{L}$ per day compared to $1.2 \pm 2.9 \mathrm{~g} / \mathrm{L}$ per day thereafter [4]. Importantly, these patients had no history of acute or recent blood loss, haematological disease, chronic renal dysfunction or renal replacement therapy. In this study, there was an inverse correlation between $[\mathrm{Hb}] \mathrm{de}-$ cline and markers of illness severity (APACHEII) $\left(r^{2}=0.28\right.$, $p<0.001)$. This rapid drop in $[\mathrm{Hb}]$ seems then to be related to severe illness, commencing before ICU admission and continuing for a short time after.

\section{Chronic anaemia in critical illness}

In Nguyen's study, there was a distinct drop-off in rate of $[\mathrm{Hb}]$ decline after the first 3 days. For those patients remaining in ICU $>3$ days, $[\mathrm{Hb}]$ decreased by $6.6 \pm 8.4 \mathrm{~g} / \mathrm{L}$ per day for the first 3 days and by $1.2 \pm 2.9 \mathrm{~g} / \mathrm{L}$ per day thereafter whilst for patients remaining in ICU $>1$ week, $[\mathrm{Hb}]$ dropped by $5.8 \pm 6.4 \mathrm{~g} / \mathrm{L}$ per day for the first 3 days and by $2.1 \pm 2.3 \mathrm{~g} / \mathrm{L}$ per day thereafter. This emphasizes two points: the decline in $[\mathrm{Hb}]$ after the acute drop slows markedly, but there is a subsequent progressive decrement in $[\mathrm{Hb}]$. Describing this chronic phase in clinical studies is made difficult by blood transfusion interventions and varying transfusion practices [8]. Considering ongoing transfusion requirements alongside the associated transfusion trigger is one method of description. In a study by Corwin et al. of patients staying in ICU $>7$ days, $85 \%$ received one or more units of blood at some point in their stay; $40 \%$ were transfused only in the first week, but the remaining $60 \%$ of patients transfused after week one had an ongoing transfusion requirement of 2 to 3 units/week thereafter with a mean pre-transfusion haematocrit of 27\% [12]. Whilst outdated phlebotomy practices accounted for some of this requirement (discussed below), more recent studies have shown a similar chronic transfusion need. In a prospective study of 100 consecutive admissions to a general ICU, the transfusion rate was $40 \%$ overall, though this climbed to $70 \%$ in those remaining in ICU $>7$ days [6]. In this study, the average pre-transfusion $[\mathrm{Hb}]$ was $73.5 \pm 4.7 \mathrm{~g} / \mathrm{L}$ and there was no association between transfusion and phlebotomy practices. Chant et al. reported the $[\mathrm{Hb}]$ variations in patients remaining in ICU for more than 30 days, excluding those with active bleeding; they found that $49 \%$ of patients received one or more PRC units after day 21 (with a mean transfusion trigger of $77 \mathrm{~g} / \mathrm{L}$ ), and those who received a transfusion had higher mean daily sequential organ failure assessment (SOFA) scores and requirements for organ support therapies [2]. Finally, considering $[\mathrm{Hb}]$ at discharge, Walsh et al. showed that $87 \%$ were anaemic, with $24 \%$ of men and $28 \%$ of women discharged with $[\mathrm{Hb}]<90 \mathrm{~g} / \mathrm{L}$ [7] whilst in a small study of 19 critical care survivors, 53\% were still anaemic 6 months after their discharge [13].

\section{Aetiology of anaemia}

An exhaustive discussion of the possible aetiologies is beyond the scope of this review. However, given the quite clear distinction between the acute and chronic $[\mathrm{Hb}]$ drop in the course of critical illness, it stands to reason that different mechanisms may be responsible for the $[\mathrm{Hb}]$ decline over these time periods; it is this that will be focused on.

\section{Haemorrhage}

In the ATICS study, of the 1,028 subjects enrolled, only $4 \%$ had a history of bleeding at ICU admission [7]. Cook et al. showed that in 1,014 mechanically ventilated patients, the incidence of clinically important gastrointestinal bleeding was 2.8\% [14]. Furthermore, in Nguyen's study, any patients with a history of recent bleeding or surgery (except where blood loss was negligible) were excluded. This suggests that the acute drop in $[\mathrm{Hb}]$ cannot be explained by haemorrhage. In contrast, a proportion of the chronic anaemia can be explained by blood loss events; in the ATICS study, clinically significant haemorrhage occurred in $21 \%$ of ICU patients and accounted for $40 \%$ of all transfusion episodes [15]. However, of all the patients transfused in this observational study, $54.7 \%$ received transfusions that were not associated with clinically significant haemorrhage emphasizing the importance of other causes of chronic anaemia in the critically ill. 


\section{Phlebotomy}

Studies in the mid 1980s demonstrated the link between phlebotomy in critical care and transfusion requirement [16]. Then, being admitted to ICU increased blood sampling from a mean of 1.1 times a day to 3.4 times a day (or four times a day if there was an indwelling arterial catheter) incurring a mean blood volume loss of $41.5 \mathrm{ml}$ per day [17] potentially accounting for the development of anaemia. Since the introduction of conservative phlebotomy techniques, it has been shown that though the average number of phlebotomies has not changed (mean of $3.5 \pm 1.04$ (SD) per patient per day), the mean blood loss can be reduced to between 8 and $22 \mathrm{ml}$ per day $[2,6,18]$, and with this, the acute drop in $[\mathrm{Hb}]$ over the first 3 days is independent of phlebotomy [6].

In those that remain in ICU $>7$ days, evidence suggests that ongoing phlebotomy may contribute significantly to anaemia. Chant et al. showed that after day 21, the number of units of RBCs transfused was significantly and independently associated with daily phlebotomy volume even when adjusted for other confounders [2].

\section{Fluid status and haemodilution}

Haemodilution occurs when plasma volume is expanded with no change in Hb-mass, resulting in an increased volume of distribution and consequently a decreased $[\mathrm{Hb}]$. On admission to ICU, the volaemic status of the patient is assessed and addressed to maintain appropriate circulatory volume and pressure. It is often necessary to give intravascular fluid in a continuous infusion or bolus form, consequently haemodiluting the patient (Figure 1). The current literature does not allow us to attribute acute anaemia to haemodilution; most studies have not accurately measured or accounted for plasma volume in their analysis. Of those that included a measure of fluid status, Nguyen et al. found that fluid balance during the first 3 days did not significantly influence the fall in [Hb] [4] (though fluid status was recorded only as 24-h fluid balance). Fully accounting for haemodilution in the acute anaemia in ICU will remain a challenge whilst $[\mathrm{Hb}]$ is used as the marker of oxygencarrying capacity. The advantages of using tHb-mass instead will be discussed later in the article.

\section{Erythropoietin deficiency}

Erythropoietin (EPO) is the major hormone regulating new red cell production in the bone marrow by inhibiting apoptosis of erythrocytic progenitor cells whilst also slowing the turnover of mature red blood cells in the reticuloendothelial system. A deficiency in EPO therefore leads to a fall in $\mathrm{Hb}$. Whilst the absolute EPO levels in critical illness are not decreased [19], there is evidence for a blunted EPO response in critically ill septic patients [9,20-23]. The likely mechanism is the inhibition of the EPO gene response elements by cytokines (IL-1, IL-6,

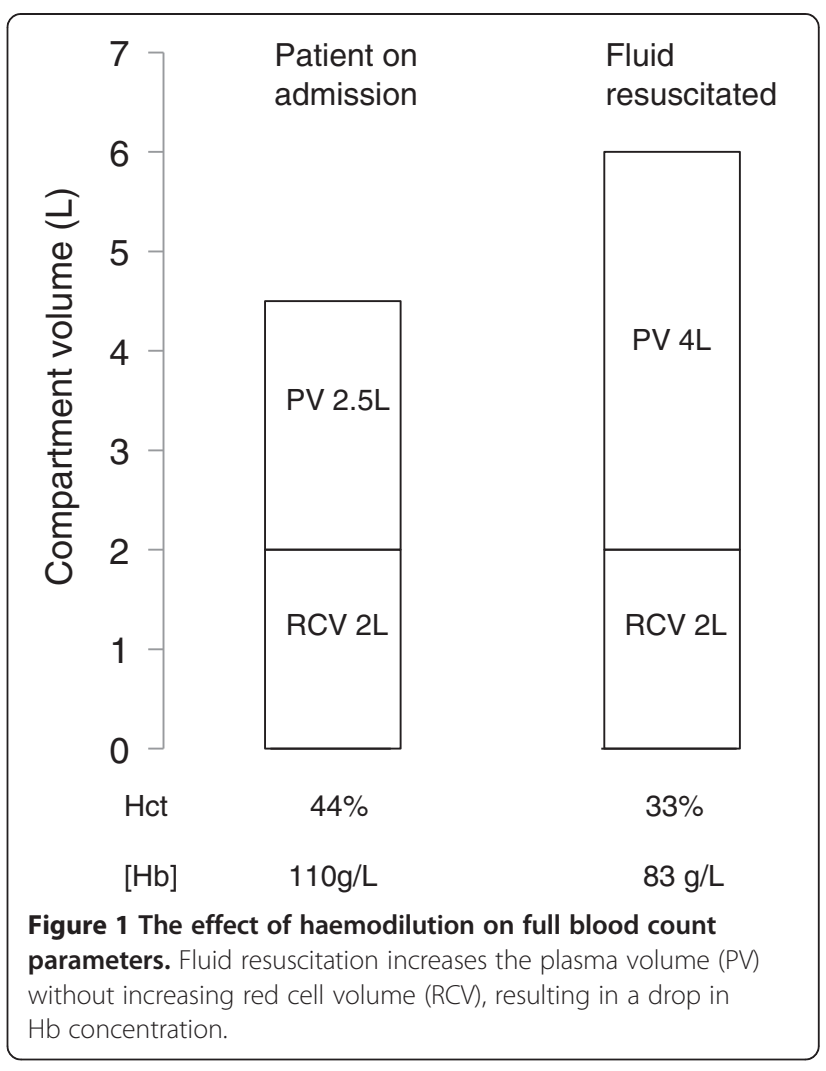

TNF $)$ [24,25] which are known to be increased in sepsis $[26,27]$. This contributes to the chronic anaemia of critical illness (in much the same way as in the anaemia of chronic disease) [28], but it cannot account for the acute drop in $[\mathrm{Hb}]$ as the effect of a fall in EPO (absolute or relative) on progenitor cell maturation would only be reflected in a falling [Hb] after approximately 10 days [29].

\section{Haemopoietic nutrient deficiency}

Efficient erythropoiesis requires not only sufficient EPO but also the availability of haemopoietic nutrients. There is evidence that in a proportion of critical ill patients, there is a deficiency in B12, folate and iron either in absolute or functional terms. In a study by Rodriguez et al. in non-bleeding, non-haemolysing medical ICU patients, on day 2 or 3 of ICU admission, 13\% were found to have nutritional deficiencies that could contribute to anaemia (9\% iron deficiency, 2\% B12 deficiency, 2\% folate deficiency) [30]. The burden of nutrient deficiency may even be higher than this due to the difficulty in assessing iron status during critical illness [31,32]; as an acute phase protein, ferritin is usually raised in critically ill patients without a change in total body ferritin [33] meaning that a 'normal' ferritin may actually reflect a total body deficit. In this way, the anaemia of critical illness resembles that of chronic disease. There is also evidence that intestinal absorption of iron may be limited in critical illness 
secondary to increased hepcidin levels. Hepcidin is a protein hormone which plays an important role in iron homeostasis by influencing intestinal iron absorption and iron release into the plasma from macrophages [34]. This occurs through interaction with the ferroportin transporter [35] which is expressed by enterocytes and reticuloendothelial macrophages. Increased hepcidin levels lead to decreased intestinal iron absorption and sequestration of iron within macrophages. Inflammation and infection increase hepcidin synthesis probably through IL-6 stimulation, and there is evidence that in critical illness, hepcidin levels are elevated [36]. This may be part of an evolutionary mechanism to protect against bacterial infection since bacteria require iron to support their growth [31]. Subsequent iron deficiency may be an unintended consequence. Furthermore, the inability to incorporate iron into erythroid precursors despite the presence of adequate iron stores, termed functional iron deficiency (FID), may result in ineffective haematopoiesis in the presence of 'normal' serum iron values. Patteril et al. showed that FID, as measured by red cell hypochromasia on flow cytometry, was present in $35 \%$ of 51 consecutive admissions in a medical ICU [37].

However, haemopoietic nutrient deficiency alone cannot explain the anaemia of critical illness; the prevalence of deficiency is low, in Patteril et al.'s study, there was no difference in $[\mathrm{Hb}]$ between FID and non-FID groups [37], and whilst nutrient insufficiency may contribute to chronic anaemia in critical illness, as with EPO insufficiency, the mechanism of decreased red cell production cannot explain the fall in $[\mathrm{Hb}]$ over the first few days.

\section{Neocytolysis}

Neocytolysis describes the programmed destruction of new red cells (neocytes). It is a mechanism first described in astronauts returning to earth after space flight $[38,39]$ and subsequently in climbers returning from high altitude $[40,41]$. In both situations, it is used to explain how red cell mass can be modulated over a short time frame of a few days leading to rapid reduction in $[\mathrm{Hb}]$; in a study of astronauts returning from space flight, red cell mass was reduced by $10 \%$ to $15 \%$ over 7 to 10 days [42]. Although the mechanism has not been clearly defined, it appears that neocytolysis is dependent on red cell splenic endothelial cell-macrophage interaction. The likely mechanisms are summarized in Figure 2. The first is dependent on decreased serum EPO levels whilst the second involves oxidative damage in neocytes. Work by Song et al. in a mouse model of neocytolysis in the setting of hypoxia-induced polycythaemia demonstrated that reticulocytes exposed to hypoxic conditions during maturation have an increased mitochondrial mass but lower levels of the reactive oxygen species (ROS) scavenging enzyme, catalase [43]. This leads to oxidative damage in the mature reticulocyte and expression of phosphatidylserine on their outer membrane and subsequent splenic consumption. Given the inflammatory state common to most critical illnesses, it is likely that erythroid progenitors are exposed to oxidative stress to oxidative stress during maturation and thus might follow this pathway. No studies have yet demonstrated neocytolysis in critical illness but it would provide a plausible explanation for the acute fall in $[\mathrm{Hb}]$ which cannot easily be explained otherwise and may contribute to the ongoing anaemia of the chronic phase. However, to suggest that neocytolysis occurs as a programmed response to critical illness is to suggest that $\mathrm{tHb}$-mass is purposefully downregulated.

\section{Anaemia and outcome in critical illness}

Evaluation of the effect of anaemia on outcome in critical illness is complicated by the impact of PRC transfusions. In addition to the complications applicable to all transfusion recipients (volume overload, transfusionrelated lung injury (TRALI) and anaphylaxis), in the critically ill, there is evidence that transfusion of PRCs can cause immunomodulation, lead to increased incidence of nosocomial infection [44] and is associated with longer ICU stay [3] and greater mortality independent of organ dysfunction $[3,5,44,45]$. The more severely anaemic patients are likely to be exposed to more transfusions and associated risk, confounding the risk of anaemia alone.

The TRICC trial provides some evidence to suggest that anaemia in critical illness is not necessarily harmful, with particular reference to acute anaemia [46]. This randomized study of non-bleeding critically ill patients with a $[\mathrm{Hb}]<90 \mathrm{~g} / \mathrm{L}$ within the first 3 days of ICU admission compared a liberal transfusion strategy (transfusion trigger $[\mathrm{Hb}]<100 \mathrm{~g} / \mathrm{L},[\mathrm{Hb}]$ aim 100 to $120 \mathrm{~g} / \mathrm{L}$ ) to a restrictive strategy (transfusion trigger $[\mathrm{Hb}]<70 \mathrm{~g} / \mathrm{L},[\mathrm{Hb}]$ aim 70 to $90 \mathrm{~g} / \mathrm{L}$ ). The result strongly suggests restricting blood transfusions to the lower trigger, with no difference in overall outcome between the groups, but a trend towards lower mortality in the restrictive group, particularly in the younger and less severely ill subgroup. The study did not use leucodepleted packed red cells and the storage age of the blood was unknown, both of which may have increased the adverse events in the liberal group. However, there is general agreement that a restrictive policy should be followed in most patients, with the exception of ischaemic cardiac cases where clarity is still required $[47,48]$. A smaller study conducted recently in 167 critically ill patients confirmed the lack of harm associated with a transfusion trigger of $70 \mathrm{~g} / \mathrm{L}$ [10]. Outside critical illness, the same has been shown in high-risk patients undergoing hip surgery [49] and in upper gastrointestinal bleeds where a restrictive strategy significantly improved outcomes [50]. There is also reason to believe that $[\mathrm{Hb}]$ lower than $70 \mathrm{~g} / \mathrm{L}$ may be well tolerated; clinical reports of Jehovah's Witness 


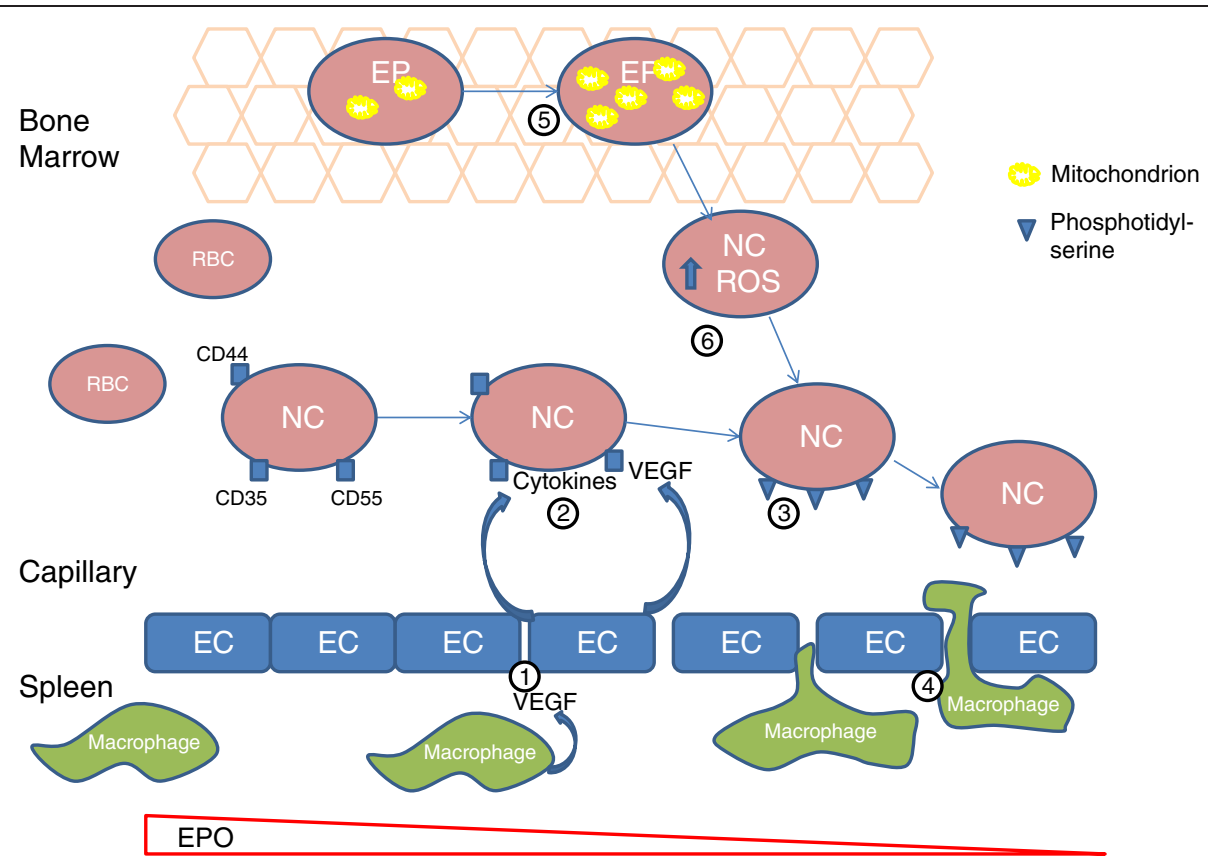

Figure 2 Proposed mechanism of neocytolysis. As the apparent concentration of EPO decreases, the permeability of the splenic endothelial cells (EC) increase (1) possibly secondary to an increase in macrophage-derived vascular endothelial growth factor (VEGF). ECs are stimulated to produce inflammatory cytokines along with VEGF (2) which cause upregulation of adhesion molecules on neocyte (NC) outer membranes and expression of phosphatidylserine (3). Macrophage processes interact with the neocytes and initiate eryptosis (4). Alternatively, erythroid progenitors (EP) in the bone marrow exposed to inflammatory conditions increase mitochondrial mass (5) which subsequently increases ROS production (6) and phosphatidylserine expression.

patients who refuse blood transfusion show mortality only increases when $[\mathrm{Hb}]$ fell below $50 \mathrm{~g} / \mathrm{L}$ [51]. A recent metaanalysis of 19 randomized controlled trials investigating anaemia in critical illness from 1956 onwards and including 6,264 patients showed that there is no association between a lower transfusion threshold ([Hb] 60 to $80 \mathrm{~g} / \mathrm{L}$ ) and any significant complication or outcome measure [52].

There are several reasons why transfusion of PRCs in critical illness may not be beneficial. First, anaemia may confer beneficial effects on cardiac output and flow characteristics in the peripheral circulation. In healthy humans, the decreased viscosity that accompanies anaemia leads to decreased left ventricular outflow impedance resulting in an increase in cardiac output [53-55]. Second, anaemia is associated with decreased systemic vascular resistance [56] whilst an increased haematocrit causes an increase in viscosity and increased vascular resistance [57]. Additionally, changes to red cell rheology and function occur in critical illness with decreased deformability [58] and increased interaction with the endothelium likely contributing to microcirculatory pathology [58-61]. In this setting, anaemia may improve peripheral perfusion.

\section{Oxygen delivery in critical illness}

Other than treating haemorrhage, the most cited indications for the transfusion of PRC units in ICU are low $[\mathrm{Hb}]$ and to increase oxygen $\left(\mathrm{O}_{2}\right)$ delivery $\left(\mathrm{DO}_{2}\right)[5,15,62]$. $\mathrm{DO}_{2}$ is determined by cardiac output $(\mathrm{CO})$ and the oxygen content of the arterial blood $\left(\mathrm{CaO}_{2}\right)$ can be expressed as:

$$
\mathrm{DO}_{2}=\mathrm{CO} \times \mathrm{CaO}_{2}
$$

$\mathrm{CaO}_{2}$ is dependent on the plasma concentration of $\mathrm{Hb}$, the oxygen-binding capacity of $\mathrm{Hb}$ (usually considered to be $1.34 \mathrm{ml} \mathrm{O}_{2}$ per gram $\mathrm{Hb}$ ) and the plasma partial pressure of $\mathrm{O}_{2}$ (which itself is a function of the solubility factor of oxygen at body temperature $\left(0.23 \mathrm{ml} \mathrm{l}^{-1} \mathrm{kPa}^{-1}\right)$. This can be calculated as follows:

$$
\begin{aligned}
\mathrm{CaO}_{2}= & \left([\mathrm{Hb}] \times \text { arterial } \mathrm{O}_{2} \text { saturation } \times 1.34 \mathrm{ml} \mathrm{O}_{2} / \mathrm{gHb}\right) \\
& +\left(0.23 \times \mathrm{PaO}_{2}\right)
\end{aligned}
$$

Using this equation, transfusion of PRCs does increase $\mathrm{DO}_{2}$ in critically ill patients [63]. However, in the critically ill, this does not translate to an increase in oxygen utilization (as measured by oxygen consumption, $\mathrm{VO}_{2}$ ) in the tissues $[8,64,65]$. In a group of septic anaemic patients, Fernandes et al. demonstrated, by way of gastric tonometry and calorimetry, no increase in global or regional oxygen utilization following PRC transfusion [66], whilst Creteur et al. showed no consistent improvement in muscle oxygen utilization using near-infrared spectroscopy (NIRS) in allcomer ICU patients following transfusion [67]. 
Table 1 The relative contribution of $[\mathrm{Hb}]$, inspired oxygen and tHb-mass on oxygen-carrying capacity

\begin{tabular}{lcccc}
\hline & Normal & $\begin{array}{c}\text { Anaemic } \\
\text { Anspired oxygen (\%) }\end{array}$ & $\begin{array}{c}\text { Anaemic }+ \\
\text { oxygen }\end{array}$ & $\begin{array}{c}\text { Decreased } \\
\text { thb-mass }\end{array}$ \\
$\mathrm{PaO}_{2}(\mathrm{kPa})$ & 12 & 21 & 100 & 21 \\
$\mathrm{SaO}_{2}(\%)$ & 98 & 98 & 98 & 85 \\
$\mathrm{Hb}$ concentration $(\mathrm{g} / \mathrm{L})$ & 150 & 75 & 75 & 75 \\
Dissolved oxygen $(\mathrm{ml} / \mathrm{L})$ & 3 & 3 & 19 & 3 \\
$\mathrm{Hb}$ bound oxygen $(\mathrm{ml} / \mathrm{L})$ & 197 & 98 & 98 & 98 \\
tHb-mass $(\mathrm{g})$ & 750 & 500 & 500 & 400 \\
Total $\mathrm{CaO}_{2[\mathrm{Hb}]}(\mathrm{ml} / \mathrm{L})$ & 200 & 101 & 117 & 101 \\
Total $\mathrm{CaO}_{2 \text { (tHb-mass) }}(\mathrm{ml})$ & 988 & 660 & 676 & 528
\end{tabular}

Adapted from SA McLellan [85] with permission. $\mathrm{PaO}_{2}$, arterial partial pressure of oxygen; $\mathrm{SaO}_{2}$, arterial oxygen saturation; $\mathrm{tHb}$-mass, total haemoglobin mass; $\mathrm{CaO}_{2}$ [Hb], oxygen-carrying capacity using [Hb]; $\mathrm{CaO}_{2}$ [tHb-mass], oxygen-carrying capacity using tHb-mass.

Some authors have suggested that this discrepancy can be explained by alterations in the oxygen-carrying and delivery capacity of transfused blood as a consequence of their storage, termed the 'storage lesion'. These changes include decreased deformability [68] and alterations in ATP and 2,3 DPG levels [69]. The effect of these changes would be decreased RBC capillary flow and decreased oxygen offloading, which are not taken into account by the calculation of $\mathrm{DO}_{2}$ outlined above. However, the storage lesion is an in vitro phenomenon, and it is not clear whether these findings are replicated in vivo [70] though a clinical study investigating the effect of RBC storage on clinical outcomes is currently underway [71].
Whether there is a storage lesion or not, there is evidence that rather than oxygen delivery failure, the problem occurs in failure to utilize the oxygen delivered; increased tissue oxygenation has been shown in the bladder epithelium of a rat model of sepsis [72] whilst increased muscle tissue oxygen tension has been shown in ICU patients with systemic sepsis compared with controls [73,74]. Meanwhile, oxygen consumption (measured by $\mathrm{VO}_{2 \max }$ ) decreases in sepsis and correlates with severity of sepsis [75]. Mitochondria are the sites of oxygen utilization, and as such, these data point toward mitochondrial dysfunction, of which there is increasing evidence [76-79].

This has led to the theory of cellular hibernation proposed by Singer $[80,81]$ which states that in the setting of sepsis, within the milieu of inflammatory cytokines and cellular dysfunction, maintaining mitochondrial mass and respiration in non-critical organs would result in increased ROS production (and potential harm to the cell) and would place an unnecessary energy demand on the body as a whole (in manufacturing mitochondrial proteins, regulating mitochondrial turnover, etc.). Instead, the cell enters a state akin to hibernation. In this situation, there is adaptive cell hypoxia where low $\mathrm{pO}_{2}$ can be tolerated due to adaptive changes in the drivers of electron transport [82-84]. This seems to be supported by evidence of early mitochondrial biogenesis being associated with survival in septic patients [78].

Overall, the extreme physiology of critical illness including adaptive cell hypoxia means that the usual employment of 'normality' in reference to $\mathrm{Hb}$ levels is unhelpful. The assumption that a normal $[\mathrm{Hb}]$ is required to optimize outcomes has been disproved. More work is

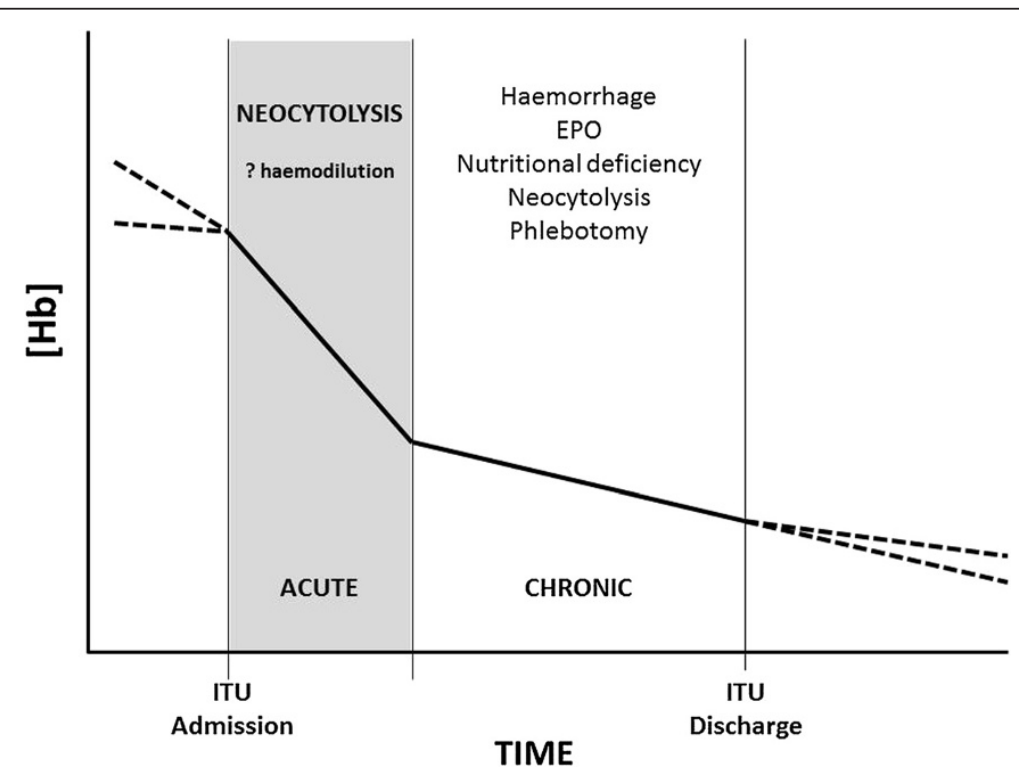

Figure 3 Phases of critical care anaemia. 
required to identify where the transfusion threshold should lie [52].

\section{tHb-mass and critical illness}

In discussing the anaemia of critical illness, a major limitation is the inherent inaccuracy associated with measuring oxygen-carrying capacity by $[\mathrm{Hb}]$ rather than tHb-mass. Concentration is dependent on the circulatory volume. As discussed previously, the fluid status of patients entering ICU differs significantly. For any given $[\mathrm{Hb}]$, patients may have very different tHb-masses [85]. Table 1 demonstrates the importance of considering tHbmass rather than $[\mathrm{Hb}]$ when calculating $\mathrm{DO}_{2}$. Considering a constant $[\mathrm{Hb}]$ of $75 \mathrm{~g} / \mathrm{L}$, increasing the inspired oxygen from $21 \%$ to $100 \%$ increases the $\mathrm{CaO}_{2}$ (tHb-mass) by $16 \mathrm{ml}$. However, if we consider that despite a constant [Hb], actual tHb-mass might vary by $20 \%$; this causes a 132-ml drop in $\mathrm{CaO}_{2}$ (tHb-mass). Furthermore, since haemodilution occurs early in ICU admission but to varying degrees, not only the initial $[\mathrm{Hb}]$ but also its trend cannot be relied upon as a marker of oxygencarrying capacity. Studies investigating indications for blood transfusion in ICU have repeatedly found that increasing oxygen-carrying capacity $[46,86]$ and low $[\mathrm{Hb}]$ $[5,62]$ are the most frequently reported reasons. It is likely therefore that a proportion of patients are being transfused unnecessarily. Given the risks associated with transfusion, any measure decreasing the number of unnecessary transfusions would be of benefit. Using tHb-mass as part of a decision tool will provide a more accurate representation of transfusion need and will allow the development of individualized patient transfusion pathways, reducing risk exposure. The most widely employed method to measure tHb-mass is the optimized carbon monoxide (CO) rebreathing method developed by Schmidt and Prommer [87], though this is not currently in use in clinical medicine. Briefly, a bolus of inhaled $\mathrm{CO}$ is used to 'tag' $\mathrm{Hb}$, and $\% \mathrm{HbCO}$ in blood is measured before and (6 and $8 \mathrm{~min}$ ) after the bolus is delivered; using the Fick principle, the tHb-mass can then be calculated. There are obvious difficulties in adapting the $\mathrm{CO}$ re-breathing method of Schmidt and Prommer to the intubated and ventilated patient. Overcoming these issues would allow transfusion requirements to be more accurately judged and would yield additional information such as an accurate calculation of the circulating plasma volume - both would be extremely valuable in treating the critically ill patient.

\section{Conclusions}

Anaemia is ubiquitous in the critically ill population. There seems to be two distinct phases: the acute phase of the first 7 days during which the drop in $[\mathrm{Hb}]$ is greatest and the chronic phase where $[\mathrm{Hb}]$ fails to recover but does not decline at the same rate. The causes of anaemia in these phases differ (Figure 3), and most of the quoted causes may contribute to the chronic anaemia but cannot explain the acute drop in $[\mathrm{Hb}]$. Neocytolysis is one mechanism by which such an acute fall in $[\mathrm{Hb}]$ could occur, and if the theory of cellular hibernation is considered, then a programmed reduction in $\mathrm{Hb}$ is logical. Neocytolysis has not yet been demonstrated in the critically ill. Finally, the development of methods to measure tHb-mass in this group is necessary if we are to more accurately assess the transfusion needs of critically ill patients.

\section{Abbreviations}

$\mathrm{CaO}_{2}$ : oxygen content of arterial blood; $\mathrm{DO}_{2}$ : oxygen delivery; $\mathrm{EPO}$ : erythropoietin; FID: functional iron deficiency; Hb: haemoglobin; ICU: intensive care unit; IL-1: interleukin 1; LL-6: interleukin 6; NIRS: near-infrared spectroscopy; $\mathrm{O}_{2}$ : oxygen; $\mathrm{PaO}_{2}$ : partial pressure of oxygen in arterial blood; $\mathrm{pO}_{2}$ : partial pressure of oxygen; PRC: packed red cells; ROS: reactive oxygen species; tHb-mass: total haemoglobin mass; TNFa: tumour necrosis factor alpha; $\mathrm{VO}_{2}$ : oxygen consumption; $\mathrm{VO}_{2}$ max: maximal oxygen consumption.

\section{Competing interests}

The authors declare that they have no competing interests.

\section{Author's contributions}

RA and ZP contributed equally to this manuscript. Both authors read and approved the final manuscript.

\section{Author details}

'Department of Medicine, UCL Institute for Human Health and Performance, University College London, 4th Floor, Rockefeller Building, 21 University Street, London WC1E 6DB, UK. ${ }^{2}$ Division of Respiratory and Critical Care Medicine, University Medicine Cluster, National University Health system, Singapore 119228, Singapore. ${ }^{3}$ Department of Medicine, Yong Loo Lin School of Medicine, National University of Singapore, Singapore 119077, Singapore.

Received: 12 September 2013 Accepted: 23 January 2014

Published: 07 Feb 2014

\section{References}

1. Corwin HL: Anemia and red blood cell transfusion in the critically ill. Semin Dial 2006, 19:513-516.

2. Chant C, Wilson G, Friedrich JO: Anemia, transfusion, and phlebotomy practices in critically ill patients with prolonged ICU length of stay: a cohort study. Crit Care 2006, 10:R140.

3. Corwin $H L$, Gettinger A, Pearl RG, Fink MP, Levy MM, Abraham E, Maclntyre NR, Shabot MM, Duh M-S, Shapiro MJ: The CRIT study: anemia and blood transfusion in the critically ill-current clinical practice in the United States. Crit Care Med 2004, 32:39-52.

4. Nguyen BV, Bota DP, Mélot C, Vincent J-L: Time course of hemoglobin concentrations in nonbleeding intensive care unit patients. Crit Care Med 2003, 31:406-410.

5. Vincent JL: Anemia and blood transfusion in critically ill patients. JAMA J Am Med Assoc 2002, 288:1499-1507.

6. Thomas J, Jensen L, Nahirniak S, Gibney RTN: Anemia and blood transfusion practices in the critically ill: a prospective cohort review. Heart Lung 2010, 39:217-225.

7. Walsh TS, Lee RJ, Maciver CR, Garrioch M, Mackirdy F, Binning AR, Cole S, McClelland DB: Anemia during and at discharge from intensive care: the impact of restrictive blood transfusion practice. Intensive Care Med 2006, 32:100-109.

8. Walsh TS, Saleh EED: Anaemia during critical illness. Br J Anaesth 2006, 97:278-291.

9. Von Ahsen N, Müller C, Serke S, Frei U, Eckardt KU: Important role of nondiagnostic blood loss and blunted erythropoietic response in the anemia of medical intensive care patients. Crit Care Med 1999, 27:2630-2639. 
10. Manoel J, li ER, Prada C, lii A, li RT, li DT, Tereza M: Red blood cell transfusions worsen the outcomes even in critically ill patients undergoing a restrictive transfusion strategy. Soa Paulo Med J 2012, 130:77-83.

11. Chohan SS, McArdle F, McClelland DBL, Mackenzie SJ, Walsh TS: Red cell transfusion practice following the transfusion requirements in critical care (TRICC) study: prospective observational cohort study in a large UK intensive care unit. Vox Sang 2003, 84:211-218.

12. Corwin $\mathrm{HL}$, Parsonnet $\mathrm{KC}$, Gettinger $\mathrm{A}$ : RBC transfusion in the ICU. Is there a reason? Chest 1995, 108:767-771.

13. Bateman AP, McArdle F, Walsh TS: Time course of anemia during six months follow up following intensive care discharge and factors associated with impaired recovery of erythropoiesis. Crit Care Med 2009, 37:1906-1912

14. Cook D, Heyland D, Griffith L, Cook R, Marshall J, Pagliarello J: Risk factors for clinically important upper gastrointestinal bleeding in patients requiring mechanical ventilation Canadian Critical Care Trials Group. Crit Care Med 1999, 27:2812-2817

15. Walsh TS, Garrioch M, Maciver C, Lee RJ, MacKirdy F, McClelland DB, Kinsella J Wallis $C$ : Red cell requirements for intensive care units adhering to evidence-based transfusion guidelines. Transfusion 2004, 44:1405-1411.

16. Henry ML, Garner WL, Fabri PJ: Iatrogenic anemia. Am J Surg 1986, 151:362-363.

17. Smoller BR, Kruskall MS: Phlebotomy for diagnostic laboratory tests in adults. Pattern of use and effect on transfusion requirements. N Engl J Med 1986, 314:1233-1235.

18. Harber CR, Sosnowski KJ, Hegde RM: Highly conservative phlebotomy in adult intensive care-a prospective randomized controlled trial. Anaesth Intensive Care 2006, 34:434-437.

19. Elliot JM, Virankabutra T, Jones S, Tanudsintum S, Lipkin G, Todd S, Bion J: Erythropoietin mimics the acute phase response in critical illness. Crit Care 2003, 7:R35-R40.

20. Van Iperen CE, Gaillard CA, Kraaijenhagen RJ, Braam BG, Marx JJ, van de Wiel A: Response of erythropoiesis and iron metabolism to recombinant human erythropoietin in intensive care unit patients. Crit Care Med 2000, 28:2773-2778.

21. Hobisch-Hagen P, Wiedermann F, Mayr A, Fries D, Jelkmann W, Fuchs D, Hasibeder W, Mutz N, Klingler A, Schobersberger W: Blunted erythropoietic response to anemia in multiply traumatized patients. Crit Care Med 2001, 29:743-747.

22. Krafte-Jacobs B, Levetown ML, Bray GL, Ruttimann UE, Pollack MM: Erythropoietin response to critical illness. Crit Care Med 1994 22:821-826.

23. Rogiers $P$, Zhang $H$, Leeman $M$, Nagler J, Neels $H$, Mélot $C$, Vincent JL: Erythropoietin response is blunted in critically ill patients. Intensive Care Med 1997, 23:159-162.

24. Frede S, Fandrey J, Pagel H, Hellwig T, Jelkmann W: Erythropoietin gene expression is suppressed after lipopolysaccharide or interleukin-1 beta injections in rats. Am J Physiol 1997, 273(3 Pt 2):R1067-R1071.

25. Jelkmann W: Proinflammatory cytokines lowering erythropoietin production. J Interferon Cytokine Res 1998, 18:555-559.

26. Goldie AS: Natural cytokine antagonists and endogenous anti endotoxin core antibodies in sepsis syndrome. JAMA J Am Med Assoc 1995, 274:172.

27. Blackwell TS, Christman JW: Sepsis and cytokines: current status. Br J Anaesth 1996, 77:110-117.

28. Corwin HL, Krantz SB: Anemia of the critically ill: "acute" anemia of chronic disease. Crit Care Med 2000, 28:3098-3099.

29. Rice L, Alfrey CP: The negative regulation of red cell mass by neocytolysis: physiologic and pathophysiologic manifestations. Cell Physiol Biochem 2005, 15:245-250.

30. Rodriguez RM, Corwin HL, Gettinger A, Corwin MJ, Gubler D, Pearl RG: Nutritional deficiencies and blunted erythropoietin response as causes of the anemia of critical illness. J Crit Care 2001, 16:36-41.

31. Darveau M, Denault AY, Blais N, Notebaert E: Bench-to-bedside review: iron metabolism in critically ill patients. Crit Care 2004, 8:356-362.

32. Pieracci FM, Barie PS: Diagnosis and management of iron-related anemias in critical illness. Crit Care Med 2006, 34:1898-1905.

33. Marshall JC: Inflammation, coagulopathy, and the pathogenesis of multiple organ dysfunction syndrome. Crit Care Med 2001, 29(7 Suppl):S99-S106
34. Andrews NC: Anemia of inflammation: the cytokine-hepcidin link. J Clin Invest 2004, 113:1251-1253.

35. Nemeth E, Tuttle MS, Powelson J, Vaughn MB, Donovan A, Ward DM, Ganz T, Kaplan J: Hepcidin regulates cellular iron efflux by binding to ferroportin and inducing its internalization. Science 2004, 306:2090-2093.

36. Heming N, Montravers $\mathrm{P}$, Lasocki S: Iron deficiency in critically ill patients: highlighting the role of hepcidin. Crit Care 2011, 15:210.

37. Patteril MV, Davey-Quinn AP, Gedney JA, Murdoch SD, Bellamy MC: Functional iron deficiency, infection and systemic inflammatory response syndrome in critical illness. Anaesth Intensive Care 2001, 29:473-478.

38. Alfrey CP, Rice L, Udden MM, Driscoll TB: Neocytolysis: physiological down-regulator of red-cell mass. Lancet 1997, 349:1389-1390.

39. Rice L, Alfrey CP: Modulation of red cell mass by neocytolysis in space and on Earth. Eur J Physiol 2000, 441:91-94

40. Rice L, Ruiz W, Driscoll T, Whitley CE, Tapia R, Hachey DL, Gonzales GF, Alfrey CP: Neocytolysis on descent from altitude: a newly recognized mechanism for the control of red cell mass. Ann Intern Med 2001, 134:652-656.

41. Risso A, Turello M, Biffoni F, Antonutto G: Red blood cell senescence and neocytolysis in humans after high altitude acclimatization. Blood Cells $\mathrm{Mol}$ Dis 2007, 38:83-92.

42. Alfrey CP, Udden MM, Leach-Huntoon C, Driscoll T, Pickett MH: Control of red blood cell mass in spaceflight. J Appl Physiol 1996, 81:98-104.

43. Song J, Yoon D, Thiagarajan P, Prchal J: Molecular basis of neocytolysis. ASH Annu Meet Abstr 2012, 120(21):2093.

44. Taylor RW, Manganaro L, O'Brien J, Trottier SJ, Parkar N, Veremakis C: Impact of allogenic packed red blood cell transfusion on nosocomial infection rates in the critically ill patient. Crit Care Med 2002, 30:2249-2254.

45. Marik PE, Corwin HL: Efficacy of red blood cell transfusion in the critically ill: a systematic review of the literature. Crit Care Med 2008, 36:2667-2674.

46. Hébert PC, Wells G, Blajchman MA, Marshall J, Martin C, Pagliarello G Tweeddale M, Schweitzer I, Yetisir E: A multicenter, randomized, controlled clinical trial of transfusion requirements in critical care. Transfusion Requirements in Critical Care Investigators, Canadian Critical Care Trials Group. N Engl J Med 1999, 340:409-417.

47. Walsh TS, Wyncoll DL, Stanworth SJ: Managing anaemia in critically ill adults. Bmj 2010, 341:C4408-c4408.

48. Carson JL, Grossman BJ, Kleinman S, Tinmouth AT, Marques MB, Fung MK, Holcomb JB, IIloh O, Kaplan LJ, Katz LM, Rao SV, Roback JD, Shander A, Tobian AAR, Weinstein R, Swinton McLaughlin LG, Djulbegovic B: Red blood cell transfusion: a clinical practice guideline from the $A A B B^{*}$. Ann Intern Med 2012, 157:49-58.

49. Carson JL, Terrin ML, Noveck H, Sanders DW, Chaitman BR, Rhoads GG, Nemo G, Dragert K, Beaupre L, Hildebrand K, Macaulay W, Lewis C, Cook DR, Dobbin G, Zakriya KJ, Apple FS, Horney RA, Magaziner J: Liberal or restrictive transfusion in high-risk patients after hip surgery. N Engl J Med 2011, 365:2453-2462.

50. Villanueva C, Colomo A, Bosch A, Concepción M, Hernandez-Gea V, Aracil C, Graupera I, Poca M, Alvarez-Urturi C, Gordillo J, Guarner-Argente C, Santaló M, Muñiz E, Guarner C: Transfusion strategies for acute upper gastrointestinal bleeding. N Engl J Med 2013, 368:11-21.

51. Viele MK, Weiskopf RB: What can we learn about the need for transfusion from patients who refuse blood? The experience with Jehovah's Witnesses. Transfusion 1994, 34:396-401.

52. Carson JL, Carless PA, Hébert PC: Outcomes using lower vs higher hemoglobin thresholds for red blood cell transfusion. JAMA 2013, 309:83-84.

53. Fowler NO, Holmes JC: Blood viscosity and cardiac output in acute experimental anemia. J Appl Physiol 1975, 39:453-456.

54. Murray JF, Escobar E, Rapaport E: Effects of blood viscosity on hemodynamic responses in acute normovolemic anemia. Am J Physiol 1969, 216:638-642.

55. Kramer $\mathrm{AH}$, Zygun DA: Anemia and red blood cell transfusion in neurocritical care. Crit Care 2009, 13:R89.

56. Weiskopf RB: Human cardiovascular and metabolic response to acute, severe isovolemic anemia. JAMA J Am Med Assoc 1998, 279:217-221.

57. Agarwal JB, Paltoo R, Palmer WH: Relative viscosity of blood at varying hematocrits in pulmonary circulation. J Appl Physiol 1970, 29:866-871.

58. Scharte M, Fink MP: Red blood cell physiology in critical illness. Crit Care Med 2003, 31(12 Suppl):S651-S657. 
59. Eichelbrönner $\mathrm{O}$, Sibbald WJ, Chin-Yee $\mathrm{H}$ : Intermittent flow increases endotoxin-induced adhesion of human erythrocytes to vascular endothelial cells. Intensive Care Med 2003, 29:709-714.

60. Eichelbrönner O, Sielenkämper A, Cepinskas G, Sibbald WJ, Chin-Yee $\mathrm{H}$ : Endotoxin promotes adhesion of human erythrocytes to human vascular endothelial cells under conditions of flow. Crit Care Med 2000, 28:1865-1870.

61. Hinshaw LB: Sepsis/septic shock: participation of the microcirculation: an abbreviated review. Crit Care Med 1996, 24:1072-1078.

62. Rao MP, Boralessa H, Morgan C, Soni N, Goldhill DR, Brett SJ, Boralessa H, Contreras M: Blood component use in critically ill patients. Anaesthesia 2002, 57:530-534.

63. Tinmouth A, Fergusson D, Yee IC, Hébert PC: Clinical consequences of red cell storage in the critically ill. Transfusion 2006, 46:2014-2027.

64. Lorente JA, Landín L, De Pablo R, Renes E, Rodríguez-Díaz R, Liste D: Effects of blood transfusion on oxygen transport variables in severe sepsis. Crit Care Med 1993, 21:1312-1318

65. Dietrich KA, Conrad SA, Hebert CA, Levy GL, Romero MD: Cardiovascular and metabolic response to red blood cell transfusion in critically ill volume-resuscitated nonsurgical patients. Crit Care Med 1990, 18:940-944.

66. Fernandes CJ, Akamine N, De Marco FV, De Souza JA, Lagudis S, Knobel E: Red blood cell transfusion does not increase oxygen consumption in critically ill septic patients. Crit Care 2001, 5:362-367.

67. Creteur J, Neves AP, Vincent J-L: Near-infrared spectroscopy technique to evaluate the effects of red blood cell transfusion on tissue oxygenation. Crit Care 2009, 13(Suppl 5):S11.

68. Peck CC, Moore GL, Bolin RB: Adenine in blood preservation. Crit Rev Clin Lab Sci 1981, 13:173-212

69. Ho J, Sibbald WJ, Chin-Yee H: Effects of storage on efficacy of red cell transfusion: when is it not safe? Crit Care Med 2003, 31(12 Suppl):S687-S697.

70. Van de Watering L: Pitfalls in the current published observational literature on the effects of red blood cell storage. Transfusion 2011, 51:1847-1854

71. Steiner ME, Assmann SF, Levy JH, Marshall J, Pulkrabek S, Sloan SR, Triulzi D, Stowell CP: Addressing the question of the effect of RBC storage on clinical outcomes: the Red Cell Storage Duration Study (RECESS) (Section 7). Transfus Apher Sci 2010, 43:107-116.

72. Rosser DM, Stidwill RP, Jacobson D, Singer M: Oxygen tension in the bladder epithelium rises in both high and low cardiac output endotoxemic sepsis. J Appl Physiol 1995, 79:1878-1882.

73. Sair M, Etherington PJ, Peter Winlove C, Evans TW: Tissue oxygenation and perfusion in patients with systemic sepsis. Crit Care Med 2001, 29:1343-1349.

74. Boekstegers P, Weidenhöfer S, Pilz G, Werdan K: Peripheral oxygen availability within skeletal muscle in sepsis and septic shock: comparison to limited infection and cardiogenic shock. Infection 1991, 19:317-323.

75. Kreymann G, Grosser S, Buggisch P, Gottschall C, Matthaei S, Greten H: Oxygen consumption and resting metabolic rate in sepsis, sepsis syndrome, and septic shock. Crit Care Med 1993, 21:1012-1019.

76. Brealey D, Brand M, Hargreaves I, Heales S, Land J, Smolenski R, Davies NA, Cooper CE, Singer M: Association between mitochondrial dysfunction and severity and outcome of septic shock. Lancet 2002, 360:219-223.

77. Ince C, Sinaasappel M: Microcirculatory oxygenation and shunting in sepsis and shock. Crit Care Med 1999, 27:1369-1377.

78. Carré JE, Orban J-C, Re L, Felsmann K, Iffert W, Bauer M, Suliman HB, Piantadosi CA, Mayhew TM, Breen P, Stotz M, Singer M: Survival in critical illness is associated with early activation of mitochondrial biogenesis. Am J Respir Crit Care Med 2010, 182:745-751.

79. Harrois A, Huet O, Duranteau J: Alterations of mitochondrial function in sepsis and critical illness. Curr Opin Anaesthesiol 2009, 22:143-149.

80. Singer M: Cellular dysfunction in sepsis. Clin Chest Med 2008, 29:655-660. viii-ix.

81. Rudiger A, Stotz M, Singer M: Cellular processes in sepsis. Swiss Med Wkly 2008, 138:629-634.

82. Connett RJ, Honig CR, Gayeski TE, Brooks GA: Defining hypoxia: a systems view of VO2, glycolysis, energetics, and intracellular PO2. J Appl Physiol 1990, 68:833-842.

83. Gøthgen $\mathrm{H}$ : What is the lower limits of arterial pO2? Acta Anaesthesiol Scand 2007, 51:393-394.

84. McLellan SA: Oxygen delivery and haemoglobin. Contin Educ Anaesthesia, Crit Care Pain 2004, 4:123-126.
85. McLellan SA, McClelland DBL, Walsh TS: Anaemia and red blood cell transfusion in the critically ill patient. Blood Rev 2003, 17:195-208.

86. Westbrook A, Pettilä V, Nichol A, Bailey MJ, Syres G, Murray L, Bellomo R, Wood E, Phillips LE, Street A, French C, Orford N, Santamaria J, Cooper DJ: Transfusion practice and guidelines in Australian and New Zealand intensive care units. Intensive Care Med 2010, 36:1138-1146.

87. Schmidt W, Prommer N: The optimised CO-rebreathing method: a new tool to determine total haemoglobin mass routinely. Eur J Appl Physiol 2005, 95:486-495.

\subsection{6/2046-7648-3-4}

Cite this article as: Astin and Puthucheary: Anaemia secondary to critical illness: an unexplained phenomenon. Extreme Physiology \& Medicine $2014,3: 4$

\section{Submit your next manuscript to BioMed Central and take full advantage of:}

- Convenient online submission

- Thorough peer review

- No space constraints or color figure charges

- Immediate publication on acceptance

- Inclusion in PubMed, CAS, Scopus and Google Scholar

- Research which is freely available for redistribution

Submit your manuscript at www.biomedcentral.com/submit
C) BioMed Central 